\title{
The HLA System and Primary Open-Angle Glaucoma
}

\author{
Reay H. Brown, Paul R. Lichter and Richard F. Haines \\ Departments of Ophthalmology and Surgery, University of Michigan Hospital, \\ Ann Arbor, Michigan, U.S.A.
}

Received for publication 7 February, revised, accepted 25 April 1978

Primary open-angle glaucoma (POAG) has been associated recently with several HLA antigens. One study of 49 POAG patients found an increase in the Bw35 antigen (46.9\% vs. $22.8 \%$ of controls) (Aviner et al. 1976). An investigation of 40 white and 40 black POAG patients failed to confirm this but found an increase in antigens $\mathrm{B} 7$ (49\% vs. $20 \%$ of controls) and B12 (50\% vs. $11 \%$ of controls) (Shin et al. 1977). This latter report indicated that either antigen B7 or B12 was present in $88 \%$ as compared to $30 \%$ of controls.

We tissue-typed 24 non-diabetic, Caucasian POAG patients using the lymphocyte microcytotoxicity technique (Ray et al. 1976). Each specimen was examined for 22 antigens by testing it against 158 antisera. The control group consisted of unrelated normal Caucasians. $P$-values were calculated by Woolf's method of relative risk and were multiplied by 22 - the total number of antigens being compared (Woolf 1955, Grumet et al. 1971).

The antigen prevalences in the POAG patients did not differ significantly from the control prevalences (Table 1).
It is not clear why three relatively similar studies all reached different conclusions. However, several of our control prevalences differed substantially from those reported by Shin et al. Their control population was racially mixed and relatively smaller (46 total, 40 whites and six blacks). The discrepancies were most marked for the associated antigens especially B12. Shin et al. reported a general prevalence for $B 12$ of $11 \%$. This is significantly different from a combined average of our value of $26 \%$ and the $24 \%$ reported by Aviner et al. $(P<0.05)$. Furthermore, Shin et al. did not multiply their $P$-values by the number of antigens under examination. This statistical correction by itself would make the elevation in B7 insignificant at the $5 \%$ level. If the correction were applied to a $P$-value for antigen B12 calculated using our control prevalence, then the reported increase in prevalence would no longer be significant.

This study does not support an association between the HLA system and POAG. In view of the conflicting results of other investigations, a strong correlation between 
POAG and an A or B locus antigen is doubtful.

Table 1

Distribution of HLA Antigens in Open-Angle Glaucoma Patients $(n=24)$ and Controls

\begin{tabular}{|c|c|c|c|}
\hline $\begin{array}{c}\text { HLA } \\
\text { Antigen }\end{array}$ & $\begin{array}{c}\text { Number of } \\
\text { Controls }\end{array}$ & $\begin{array}{c}\text { Percent } \\
\text { of POAG } \\
\text { Patients } \\
\text { with } \\
\text { Antigen }\end{array}$ & $\begin{array}{c}\text { Percent of } \\
\text { Controls } \\
\text { with } \\
\text { Antigen(s) }\end{array}$ \\
\hline A1 & 612 & 33 & 28 \\
\hline A2 & 612 & 42 & 50 \\
\hline A3 & 612 & 25 & 24 \\
\hline A11 & 608 & 13 & 13 \\
\hline Aw24 & 467 & 21 & 15 \\
\hline Aw 25 & 446 & 4.2 & 45 \\
\hline Aw26 & 489 & 8.3 & 4.9 \\
\hline A29 & 557 & 13 & 7.4 \\
\hline Aw 30 & 401 & 4.2 & 4.2 \\
\hline Aw 31 & 401 & 17 & 6.5 \\
\hline Aw 32 & 401 & 4.2 & 4.5 \\
\hline B5 & 612 & 8.3 & 12 \\
\hline B7 & 612 & 25 & 26 \\
\hline B8 & 612 & 29 & 19 \\
\hline B12 & 612 & 29 & 26 \\
\hline B13 & 594 & 42 & 3.9 \\
\hline B14 & 599 & 4.2 & 7.8 \\
\hline Bw15 & 599 & 83 & 12 \\
\hline B18 & 599 & 83 & 9.0 \\
\hline B27 & 594 & 8.3 & 8.2 \\
\hline Bw35 & 612 & 25 & 17 \\
\hline Bw40 & 611 & 21 & 15 \\
\hline \multicolumn{4}{|l|}{ B7 and/or } \\
\hline B12 & 612 & 54 & 48 \\
\hline
\end{tabular}

References

Aviner, Z., Henley, W. L., Fontino, M. \& Leopold, I. H. (1976) Histocompatibility (HLA) antigens and primary open-angle glaucoma. Tissue Antigens 7, 193-200.

Grumet, F. C., Coukell, A., Bodmer, J. G., Bodmer, W. F. \& McDevitt, H. O. (1971) Histocompatibility (HL-A) antigens associated with systemic lupus ery thematosus. New Engl. J. Med. 285, 193-196.

Ray, J. G., Jr., Hare, D. B., Pedersen, P. D. \& Mullally, D. I. (1976) Manual of Tissue Typing Tecbniques. Department of Health, Education and Welfare Publications, National Institute of Health, Transplantation and Immunology Branch, Bethesda, Md.

Shin, D. H., Becker, B., Waltman, S. R., Palmberg, P. F., \& Bell, C. E. (1977) The prevalence of HLA-B12 and HLA-B7 antigens in primary open-angle glaucoma. Arch. Opbthal. 95, 224-225.

Woolf, B. (1955) On estimating the relation between blood group and disease. Ann. bum. Genet. 19, 251-253.

Address:

Paul R. Licbter, M.D.

Department of Ophthalmology

C-6058 - Outpatient Building

University of Michigan Hospital

Ann Arbor, MI 48109

U.S.A. 